\title{
Association of 'Candidatus Liberibacter solanacearum' with a Vegetative Disorder of Celery in Spain and Development of a Real-Time PCR Method for Its Detection
}

\author{
Gabriela R. Teresani, Edson Bertolini, Ana Alfaro-Fernández, Carmen Martínez, Francisco André Ossamu Tanaka, \\ Elliot W. Kitajima, Montserrat Roselló, Susana Sanjuán, Juan Carlos Ferrándiz, \\ María M. López, Mariano Cambra, and María Isabel Font
}

First, second, fourth, tenth, and eleventh authors: Plant Protection and Biotechnology Center, Instituto Valenciano de Investigaciones Agrarias (IVIA), 46113 Moncada, Valencia, Spain; third and twelfth authors: Grupo Virología Vegetal, Instituto Agroforestal Mediterráneo, Universidad Politécnica de Valencia, 46022 Valencia, Spain; fifth and sixth authors: Escola Superior de Agricultura Luiz de Queiroz, Universidade de São Paulo, 13418-900 Piracicaba, Brazil; seventh author: Servicio de Análisis Agroalimentario, Conselleria de Presidencia y de Agricultura, Pesca, Alimentación y Agua, Generalitat Valenciana, 46460 Silla, Valencia, Spain; and eighth and ninth authors: Departamento Técnico, Agrícola Villena Coop, V. 03400 Villena, Alicante, Spain.

Accepted for publication 30 January 2014.

\begin{abstract}
Teresani, G. R., Bertolini, E., Alfaro-Fernández, A., Martínez, C., Tanaka, F. A. O., Kitajima, E. W., Roselló, M., Sanjuán, S., Ferrándiz, J. C., López, M. M., Cambra, M., and Font, M. I. 2014. Association of 'Candidatus Liberibacter solanacearum' with a vegetative disorder of celery in Spain and development of a real-time PCR method for its detection. Phytopathology 104:804-811.

A new symptomatology was observed in celery (Apium graveolens) in Villena, Spain in 2008. Symptomatology included an abnormal amount of shoots per plant and curled stems. These vegetative disorders were

phytoplasmas. Samples from plant sap were immobilized on membranes based on the spot procedure and tested using a newly developed real-time polymerase chain reaction assay to detect ' $\mathrm{C} a$. L. solanacearum'. Then, a test kit was developed and validated by intralaboratory assays with an accuracy of $100 \%$. Bacterial-like cells with typical morphology of ' $\mathrm{Ca}$. Liberibacter' were observed using electron microscopy in celery plant tissues. A fifth haplotype of ' $\mathrm{Ca}$. L. solanacearum', named E, was identified in celery and in carrot after analyzing partial sequences of $16 \mathrm{~S}$ and 50S ribosomal RNA genes. From our results, celery (family Apiaceae) can be listed as a new natural host of this emerging bacterium.
\end{abstract} associated with 'Candidatus Liberibacter solanacearum' and not with
Celery (Apium graveolens L., family Apiaceae) cultivation is of increasing interest in European countries. In Spain, there are $\approx 1,640$ ha of celery crops, mainly in the Mediterranean regions, which account for an annual production of 80,000 t. Celery is affected by fungal, viral, and bacterial pathogens causing various well-known diseases (36). In 2008 in Villena, Alicante, Spain, celery plants showed symptoms that had not been observed before (i.e., abnormal amount of shoots, curling of stems, and yellowing) (Fig. 1A to D). These vegetative disorders were observed in the crop in the three overlapping cultivation cycles (early, medium, and late) from March to November in 'Loretta', 'Monterrey', and 'Imperial' of A. graveolens var. dulce (Mill.). Only severe stunting appeared in 'Brillant' of A. graveolens var. rapaceum (Mill). Consequently, there was a relevant yield reduction and economic losses from 2008 to 2009 in Villena, followed by other Spanish celery-growing regions. Celery was grown in these areas together with carrot (Daucus carota, family Apiaceae) in plots that exhibited a high prevalence of 'Candidatus Liberibacter solanacearum'-infected plants $(10,25)$.

' $C a$. L. solanacearum', also named as 'Ca. L. psyllaurous' (12), is a Gram-negative bacterium. It cannot be cultured in vitro yet. It is restricted to the plant's phloem, transmitted through vegetative

\section{Corresponding author: M. Cambra; E-mail address: mcambra@ivia.es}

* The $\boldsymbol{e}$-Xtra logo stands for "electronic extra" and indicates that Figure 1 appears in color online.

http://dx.doi.org/10.1094/PHYTO-07-13-0182-R

(c) 2014 The American Phytopathological Society propagation and naturally by several psyllid species (23). ' $\mathrm{Ca}$. L. solanacearum' causes a disease affecting potato (zebra chip) (38). In addition to causing disease in potato, ' $\mathrm{Ca}$. L. solanacearum' can cause serious damage and economic losses in tomato (Solanum lycopersicum), pepper (Capsicum annuum), eggplant (S. melongena), tamarillo ( $S$. betaceum), tomatillo (Physalis peruviana), tobacco (Nicotiana tabacum), carrot, and weeds in the family Solanaceae $(10,23)$.

The bacterium is transmitted in a persistent (transovarial) way by the psyllid Bactericera cockerelli (24). It has also been detected in the psyllids Trioza apicalis (25), B. trigonica (2), other Trioza spp., and Accizia spp. (37).

Conventional and real-time polymerase chain reaction (PCR) methods have been developed to detect or identify ' $C a$. L. solanacearum' in plant material and insect vectors $(8,12,16,18$ 20,26,33,34,42). In most bacterial models, real-time PCR has advantages over conventional PCR because it is more sensitive and reliable $(9,16)$. The PCR templates require extract preparation and nucleic acid purification, which is laborious and time consuming and increases the risk of contamination (32). The nucleic acid purification step can be overcome using direct sample preparation methods such as tissue-print or squash or spot immobilization on membranes (9). The main drawback of target immobilization is the small amount of target nucleic acid available on the support. This limitation can be offset by coupling these preparation methods with highly sensitive techniques such as real-time PCR (4).

In this article, we present the first formal scientific report of the presence of ' $\mathrm{Ca}$. L. solanacearum' in celery in Spain and describe 
its haplotype and the symptoms that it causes in celery. A detection method for ' $\mathrm{Ca}$. L. solanacearum' using sample immobilization on membranes and a complete kit for accurate detection of the bacterium based on universal ' $\mathrm{Ca}$. Liberibacter' primers and a specific probe for real-time PCR are developed and validated as well.

\section{MATERIALS AND METHODS}

Plant material and prevalence of symptoms. In all, $\approx 37$ ha of celery crops were annually inspected by technical staff from Agrícola Villena cooperative (Villena Coop. V., which produces $20 \%$ of the fresh celery and carrot in Spain). Inspections were conducted on the field and in the packinghouse from 2008 to 2012 at Villena, Alicante, Spain to estimate the percentage of field plants showing symptoms and the number of packinghouse discards. During this period, 2,655 celery plants were randomly collected from experimental plots to estimate the prevalence of the disorder or ' $\mathrm{Ca}$. L. solanacearum'.

In September 2010, at harvest, 502 plants of 'Loretta', 'Imperial', and 'Monterrey' celery from experimental plots were classified into three categories according to the severity of the symptoms. The classification was as follows: (i) 174 plants as "+++", with severe symptoms making the celery unmarketable (Fig. 1A and B); (ii) 150 plants as "+", with mild symptoms that could be marketed; and (iii) 178 symptomless and marketable plants. Each sample was tested for ' $C a$. L. solanacearum' and phytoplasmas to investigate the etiology of the disorders. Healthy and diseased 'Maestro' and 'Bangor' carrot plants, growing together with celery, that tested negative and positive, respectively, against ' $C a$. L. solanacearum', were collected in April 2010. The plants were transplanted to pots and grown in a greenhouse (P2 level of biological containment) and used as controls.

Sample preparation. Leaf samples $(\approx 1 \mathrm{~g} /$ plant $)$ were collected from the middle part of celery and carrot plants into separate plastic bags and stored at $4{ }^{\circ} \mathrm{C}$ for up to 1 week until use. Extracts were prepared using a Homex 6 (Bioreba, Switzerland) homogenizer, grinding the plant material $1: 5$ to $10(\mathrm{wt} / \mathrm{vol})$ in phosphate-buffered saline (PBS) extraction buffer $(\mathrm{NaCl}, 8 \mathrm{~g} /$ liter; $\mathrm{NaH}_{2} \mathrm{PO}_{4} \cdot 2 \mathrm{H}_{2} \mathrm{O}, 0.4 \mathrm{~g} /$ liter; and $\mathrm{Na}_{2} \mathrm{HPO}_{4} \cdot 12 \mathrm{H}_{2} \mathrm{O}, 2.7 \mathrm{~g} / \mathrm{liter}$ $\mathrm{pH}$ 7.2). Extract ( $1 \mathrm{ml}$ from each plant) was stored at $-20^{\circ} \mathrm{C}$ until use.

Direct sample preparation without DNA purification (spot procedure). Freshly prepared or frozen plant extracts were
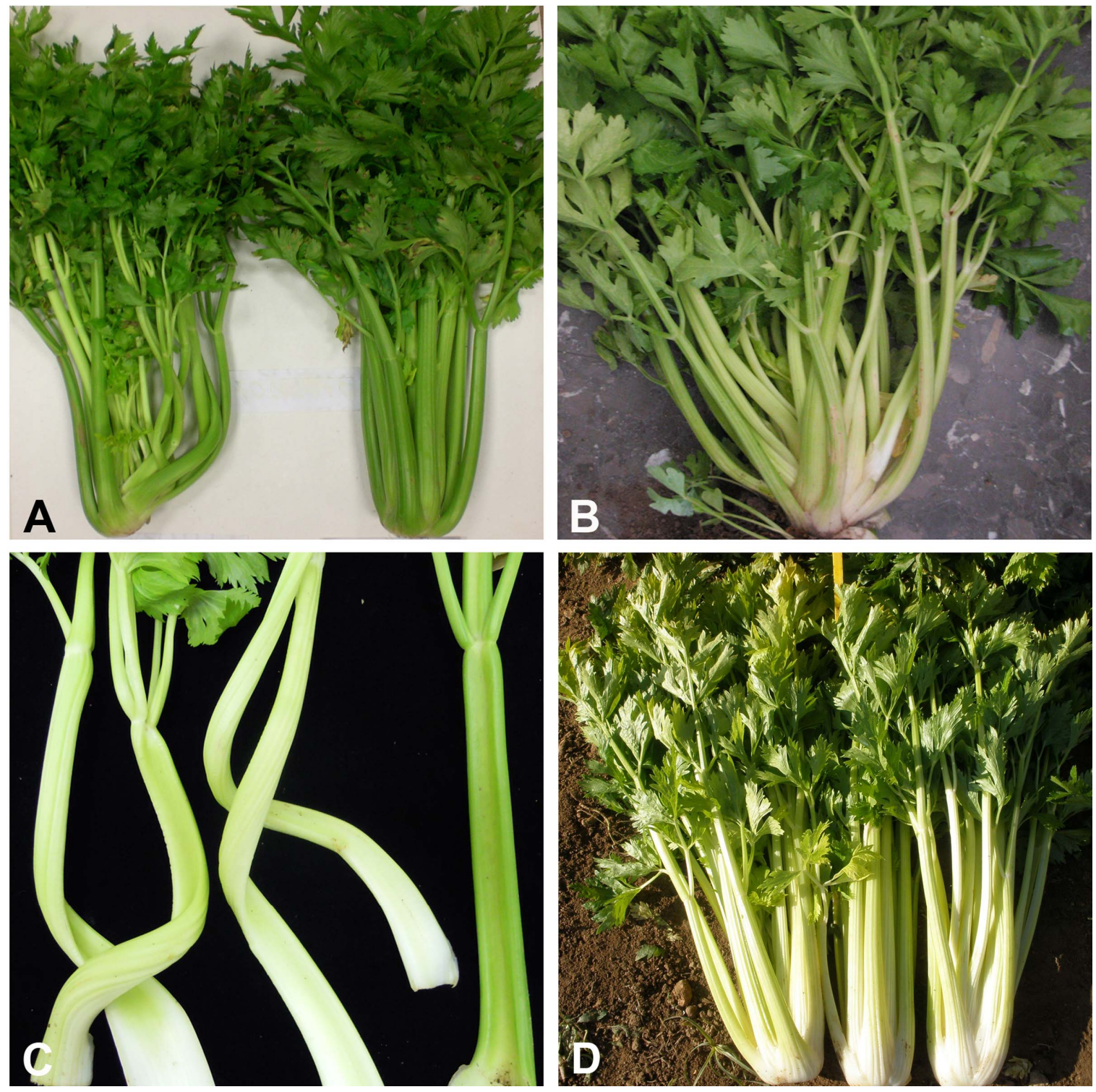

Fig. 1. Severe symptoms in celery plants associated with 'Candidatus Liberibacter solanacearum'. A, Abnormal amount of shoots and curling of stems (left) compared with a symptomless plant (right). B, Proliferation, abnormal amount of shoots. C, Curling of stems (left) compared with a normal stem (right). D, Mild symptoms in marketable plants. 
immobilized on membranes (32) by spotting $5 \mu \mathrm{l}$ of crude plant extract onto pieces $\left(\approx 0.5 \mathrm{~cm}^{2}\right)$ of positively charged nylon membrane (Roche, Mannheim, Germany) or Whatman 3MM filter paper (GE Healthcare Europe $\mathrm{GmbH}$, Freiburg, Germany), in Eppendorf tubes (7). Spotted plant extracts were left to dry for 5 min and then stored at room temperature in the dark until required. The DNA was released from each membrane by adding $100 \mu \mathrm{l}$ of distilled water per tube (3). Each tube was then vortexed and placed on ice. Then, $3 \mu$ from this preparation was used as the template for real-time PCR.

DNA purification. Total DNA was purified from $200 \mu \mathrm{l}$ of crude plant extract by using the DNeasy Plant Mini Kit (Qiagen, Hilden, Germany) according to the manufacturer's protocol or the cetyltrimethyl ammonium bromide (CTAB) protocol (29). Purified DNA was stored at $-20^{\circ} \mathrm{C}$ until use. These DNA templates were considered as the "gold-standard" when comparing the conventional method using purified DNA and the direct methods of sample preparation without DNA purification.

Comparison of sample preparation methods using naturally infected celery plants: DNA extraction versus spot. The 502 plants of 'Loretta', 'Imperial', and 'Monterrey' celery from experimental plots (described above) were tested using two sample preparation methods: DNA extraction (considered as the gold standard technique) (29) and the spot procedure (32). Cohen's $\kappa$ coefficient and the bias-adjusted $\kappa(B A K)$ index were used to calculate the coincidental results between methods (6). Both sample preparation methods were compared using the same plant extract and the newly developed real-time PCR protocol (see below).

Probe design. Nucleotide sequences internal to patented universal ' $C a$. Liberibacter' spp. forward CaLsppF (5'-GCAG GCCTAACACATGCAAGT-3') and reverse CaLsppR 5'-(GCAC ACGTTTCCATGCGTTAT-3') (3) primers were selected to design a ' $C a$. L. solanacearum'-specific probe. Alignment of nucleotides based on the $16 \mathrm{~S}$ ribosomal DNA (rDNA) sequences of ' $\mathrm{Ca}$. L. solanacearum' recovered from GenBank was performed. Primer Express software (Applied Biosystems, Foster City, CA) was used to design the specific CaLsolP probe. The probe was labeled with fluorescent dyes 5'FAM-AGCGCTTATTTTTAATAGGAGCGG CAGACG-3' TAMRA.

Real-time PCR. Real-time PCR using CaLsppF and CaLsppR primers and the newly designed (CaLsolP) TaqMan probe was carried out using two real-time PCR systems: StepOne Plus (Applied Biosystems) and Light Cycler 480 (Roche). Various concentrations of primers $(0.3$ to $1.0 \mu \mathrm{M})$ and probe (80 to $300 \mathrm{nM}$ ) were used to test the optimum amplification conditions. The optimum reaction mix consisted of $1 \times$ Path-IDTM qPCR master mix (Ambion, Grand Island, NY), $0.5 \mu \mathrm{M}$ each CaLsppF and CaLsppR primer, $150 \mathrm{nM}$ CaLsolP TaqMan probe, and $3 \mu \mathrm{l}$ of purified DNA or DNA from the spotted samples in a final volume of $12 \mu \mathrm{l}$. Purified DNA and spots of crude extracts prepared from symptomatic carrot or celery plants infected with 'Ca. L. solanacearum' were used as positive controls in each PCR. Purified DNA and spots of crude extracts from healthy carrot or celery plants, DNAse-free distilled water, and nonspotted pieces of membrane were used as negative controls in each PCR assay. The real-time PCR amplification protocol consisted of $95^{\circ} \mathrm{C}$ for $10 \mathrm{~min}$ followed by 45 cycles of $95^{\circ} \mathrm{C}$ for $15 \mathrm{~s}$ and $60^{\circ} \mathrm{C}$ for $1 \mathrm{~min}$. Data acquisition and analysis were performed with the thermal cycler's software. The default threshold set by the machine was slightly adjusted above the noise in the linear part of the growth curve. This new real-time assay was compared with the procedure of Li et al. (16).

Specificity and sensitivity. In total, 110 reference ' $\mathrm{Ca}$. L. solanacearum' DNA samples from 10 different origins, 17 DNA samples of ' $C a$. Liberibacter' species other than ' $C a$. L. solanacearum', 16 strains of bacterial species that affect solanaceous and other crops, and 81 unidentified bacterial isolates from celery, carrot, and potato microbiota (Table 1) were used to test specificity of the new real-time assay. Sensitivity was tested using serial dilutions of a ' $\mathrm{Ca}$. L. solanacearum'-positive 'Loretta' celery extract (prepared by homogenizing 1:10 [wt/vol] plant material in PBS buffer, $\mathrm{pH}$ 7.2) in a healthy celery extract of the same cultivar (negative to ' $\mathrm{Ca}$. L. solanacearum' by PCR). A sample of each dilution was spotted on Whatman 3MM paper or used for DNA purification. Spotted extracts and purified DNA were used to compare four conventional (see below) and two realtime PCR protocols.

Conventional PCR protocols. Four previously described conventional PCR protocols using different primers were compared: OA2 and OI2c (17), Lso TX F and Lso TX R, Lso adk F and Lso adk R (33), LsoF and OI2c (16). Amplifications were performed as described by these authors. Purified DNA and spots of crude extracts prepared from symptomatic carrot or celery plants infected with ' $C a$. L. solanacearum' were used as positive controls in each PCR. Purified DNA and spots of crude extracts from healthy carrot or celery plants, DNAse-free distilled water, and nonspotted pieces of membrane were used as negative controls in each PCR assay.

Intralaboratory validation of a complete kit. A complete kit (Ref. CaLsol/100; Plant Print Diagnòstics SL, Valencia, Spain) for accurate detection of the bacterium was developed based on the new real-time assay and primers (3). The kit used lyophilized master mix and was based on a direct method of sample preparation. The kit was tested in three different laboratories at Instituto Valenciano de Investigaciones Agrarias using three different real-time PCR systems (StepOne Plus and LightCycler 480, described earlier, and SmartCycler-Cepheid). In all, 10 blind samples immobilized on Whatman 3MM filter paper were used: five positive for ' $\mathrm{Ca}$. L. solanacearum' and five negative. Template preparation was performed according to the kit manufacturer's instructions. Positive samples were ' $\mathrm{Ca}$. L. solanacearum'infected extracts from carrot and celery plants. Negative samples were extracts from healthy carrot, celery, potato, $N$. benthamiana, and periwinkle. The amplification conditions for the kit were $4^{\circ} \mathrm{C}$ higher than those described previously for real-time amplification using fresh (nonlyophilized) master mix. Six replicate reactions were performed on each sample. Diagnostic parameters (sensitivity, specificity, and accuracy) were calculated according to https: //www.antonio-olmos.com/parameters/online/calculator.html. Positive or negative results and cycle threshold $(\mathrm{Ct})$ values were recorded for each sample.

Association of ' $\mathrm{Ca}$. L. solanacearum' or phytoplasmas with symptoms. The 502 plants of celery from experimental plots (described above) were tested for ' $\mathrm{Ca}$. L. solanacearum' using the real-time PCR kit described in this article and for phytoplasmas using the procedure of Hren et al. (13). Results were compared using multinomial regression analysis ('Program R', www.rproject.org). Phytoplasmas were included in this study because they can cause symptoms similar to those caused by ' $\mathrm{Ca}$. L. solanacearum' on some plant species.

Electron microscopy. Leaf midribs from symptomatic plants that had tested real-time PCR positive for ' $\mathrm{Ca}$. L. solanacearum' from commercial celery fields were prepared for transmission (TEM) and scanning (SEM) electron microscopy. For TEM analyses, midribs were first fixed in Karnovisky solution for $24 \mathrm{~h}$, then fixed with osmium tetroxide in $1 \%$ cacodylate buffer for $1 \mathrm{~h}$ and contrasted with uranyl acetate $0.5 \%$ overnight. Samples were then dehydrated using increasing concentrations of acetone (30 to $100 \%)$. Infiltration and embedding was performed in 1:1 acetone $(100 \%) / S p u r r$ epoxy resin for at least $5 \mathrm{~h}$ and then in pure resin Spurr overnight or longer, depending on the infiltration capacity of the samples. Polymerization was carried out at $70^{\circ} \mathrm{C}$ for 3 days. The resin blocks were cut into 70-nm sections (using an ultramicrotome with diamond knife), which were placed on copper's screens, contrasted with uranyl acetate $3 \%$ and lead citrate (35). 
Samples were examined using a JEOL JEM 1011 transmission electron microscope and images were captured using a digital camera.

For SEM analyses, midribs were fixed with Karnovisky solution for $24 \mathrm{~h}$, infiltrated with glycerol, immersed in liquid nitrogen, and fractured with a scalpel. Fractured pieces were postfixed in $0.1 \% \mathrm{OsO}_{4}$ for $1 \mathrm{~h}$, dehydrated in acetone, dried at the critical point, gold coated by sputtering, and examined in a LEO 435 VP scanning electron microscope (39).

Phylogenetic analyses. The phylogenetic analyses were performed to determine haplotypes and to establish the relationship with other available sequences of ' $\mathrm{Ca}$. L. solanacearum' in different regions and hosts. ' $C a$. L. solanacearum' PCR products from celery and carrot, amplified with $16 \mathrm{~S}$ rDNA OA2/OI2c primers $(1,168 \mathrm{bp})$ and with 50S rDNA rplj CL514F/CL514R primers (669 bp) (28), were purified using the High Pure PCR Product Purification Kit (Roche) and sequenced. Sequences were compared with 23 sequences from other hosts in GenBank (National Center for Biotechnology Information). Nucleotide sequences were aligned using ClustalW software implemented in the Geneious program. Phylogenetic trees were inferred using
MEGA 5.1 and the neighbor-joining algorithm (14), with 1,000 bootstrap replicates.

Six ' $C a$. L. solanacearum' sequences from celery and two from carrot based on $16 \mathrm{~S}$ rRNA, $16 \mathrm{~S} / 23 \mathrm{~S}$ intergenic spacer region (ISR), and 50S rRNA genes obtained in this work, and four sequences from the previously described haplotypes (A, B, C, and $\mathrm{D})$, were aligned within the respective gene regions using the Geneious program. The single-nucleotide polymorphisms (SNPs) were visually identified and annotated. A phylogenetic tree was constructed with MEGA 5.1 using the unweighted pairgroup method with arithmetic means algorithm.

\section{RESULTS}

Prevalence of symptoms and ' $\mathrm{Ca}$. L. solanacearum' detection. The prevalence of symptoms in celery cultivars in Villena was 50\% (2008), 60\% (2009), 32\% (2010), 0.8\% (2011), and $0.1 \%$ (2012). 'Loretta' was the most susceptible, showing symptoms in up to $70 \%$ of the plants in 2009 and 2010. 'Imperial' followed by 'Monterrey' were less susceptible. The number of positive plants for ' $\mathrm{Ca}$. L. solanacearum' out of the total number

TABLE 1. 'Candidatus Liberibacter' spp. used for detection in various plant hosts using real-time polymerase chain reaction (PCR)

\begin{tabular}{|c|c|c|c|c|}
\hline Bacterial isolates and strains & Host, year & Number & Origin (reference) $)^{\mathrm{a}}$ & $\begin{array}{c}\text { Real-time PCR } \\
\text { CaLsppF/CaLsppR }\end{array}$ \\
\hline 'Candidatus Liberibacter solanacearum' & Apium graveolens, 2010 & 10 & Villena-Spain (IVIA-A10.1-10) & + \\
\hline 'Ca. L. solanacearum' & A. graveolens, 2011 & 10 & Villena-Spain (IVIA-A11.1-10) & + \\
\hline 'Ca. L. solanacearum' & A. graveolens, 2012 & 15 & Villena-Spain (IVIA-A12.1-15) & + \\
\hline 'Ca. L. solanacearum' & Bactericera trigonica, 2010 & 10 & Canary Islands-Spain (ICIA-Bt10.1-10) & + \\
\hline 'Ca. L. solanacearum' & B. trigonica, 2011 & 10 & Canary Islands-Spain (IVIA-Bt11.1-10) & + \\
\hline 'Ca. L. solanacearum' & B. nigricornis, 2012 & 10 & La Rioja-Spain (IVIA-Bn 12.1-10) & + \\
\hline 'Ca. L. solanacearum' & Daucus carota, 2010 & 15 & Villena-Spain (IVIA-Z10.1-15) & + \\
\hline 'Ca. L. solanacearum' & D. carota, 2010 & 10 & Canary Islands-Spain (ICIA-Z10.1-10) & + \\
\hline 'Ca. L. solanacearum' & D. carota, 2011 & 10 & Villena-Spain (IVIA-Z11.1-10) & + \\
\hline 'Ca. L. solanacearum' & D. carota, 2012 & 10 & Canary Islands-Spain (ICIA-Z12.1-10) & + \\
\hline 'Ca. L. americanus' & Catharanthus roseus & 1 & Brazil* & - \\
\hline 'Ca. L. americanus' & Citrus sp. & 1 & Brazil* & - \\
\hline 'Ca. L. asiaticus' & Citrus sp. & 1 & Brazil & - \\
\hline 'Ca. L. asiaticus' & C. roseus & 1 & China* & - \\
\hline 'Ca. L. asiaticus' & C. roseus & 1 & Philippines* & - \\
\hline 'Ca. L. asiaticus' & Citrus sp. & 1 & Philippines (PH 70)* & - \\
\hline 'Ca. L. asiaticus' & C. roseus & 1 & Florida-USA* & - \\
\hline 'Ca. L. asiaticus' & C. roseus & 1 & India (Poona 70)* & - \\
\hline 'Ca. L. asiaticus' & Citrus sp. & 1 & India (Poona 70)* & - \\
\hline 'Ca. L. asiaticus' & Citrus sp. & 1 & Indonesia-Bali* & - \\
\hline 'Ca. L. asiaticus' & Citrus sp. & 1 & Malaysia $(95-1)^{*}$ & - \\
\hline 'Ca. L. asiaticus' & Citrus sp. & 1 & Mauritius Island $(95-11)^{*}$ & - \\
\hline 'Ca. L. africanus' & Citrus sp. & 1 & Reunion Island-France (USA-7)* & - \\
\hline 'Ca. L. africanus' & C. roseus & 1 & South Africa (AFS 84)* & - \\
\hline 'Ca. L. asiaticus' & Citrus sp. & 1 & Taiwan (LK 70)* & - \\
\hline 'Ca. L. asiaticus' & C. roseus & 1 & Thailand (TH 88)* & - \\
\hline 'Ca. L. asiaticus' & Citrus sp. & 1 & Vietnam $(95-35)^{*}$ & - \\
\hline Agrobacterium tumefaciens & Prunus sp. & 1 & USA (C 58) & - \\
\hline Clavibacter michiganensis subsp. michiganensis & Solanum lycopersicum & 1 & Spain (IVIA 873-6) & - \\
\hline C. michiganensis subsp. sepedonicus & S. tuberosum & 1 & USA (NCPPB 2140) & - \\
\hline Dickeya sp. & S. tuberosum & 1 & Spain (IVIA 1374-13) & - \\
\hline Dickeya sp. & S. tuberosum & 1 & Spain (IVIA 2688-1-2) & - \\
\hline Pectobacterium atrosepticum & S. tuberosum & 1 & United Kingdom (SCRI 1001) & - \\
\hline P. carotovorum & S. tuberosum & 1 & United Kingdom (SCRI 194) & - \\
\hline Pseudomonas cichorii & Lactuca sativa & 1 & Spain (IVIA 593) & - \\
\hline P. corrugata & S. lycopersicum & 1 & UK (NCPPB 2445) & - \\
\hline P. mediterranea & S. lycopersicum & 1 & Spain (IVIA 592-4-4) & - \\
\hline P. syringae pv. syringae & Pyrus communis & 1 & Spain (IVIA 773-1) & - \\
\hline P. syringae pv. tomato & S. lycopersicum & 1 & Spain (IVIA 1001-1a) & - \\
\hline Ralstonia solanacearum & S. tuberosum & 1 & Spain (IVIA 1602) & - \\
\hline Rhodococcus fascians & Dahlia sp. & 1 & France (CFBP 41) & - \\
\hline Rhodococcus sp. & Nicotiana tabaccum & 1 & Spain (IVIA 4264) & - \\
\hline Xanthomonas vesicatoria & S. lycopersicum & 1 & Spain (IVIA 3617) & - \\
\hline Microbiota strains & S. tuberosum & 50 & Spain (IVIA $1 \mathrm{~F}$ to $50 \mathrm{~F}$ ) & - \\
\hline Microbiota strains & D. carota & 21 & Spain (IVIA $3925-1$ to $3925-21$ ) & - \\
\hline Microbiota strains & A. graveolens & 10 & Spain (IVIA AM-1 to AM-10) & - \\
\hline
\end{tabular}

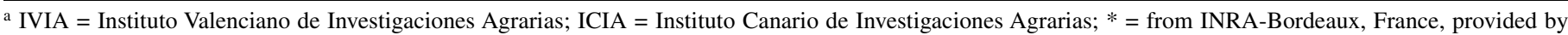
J. M. Bové; NCPPB = National Collection of Plant Pathogenic Bacteria; and SCRI = Scottish Crop Research Institute. 
of randomly tested plants was $32 / 52(62 \%)$ in 2009, 252/503 $(50 \%)$ in $2010,82 / 900(9 \%)$ in 2011 , and $6 / 1200(0.5 \%)$ in 2012.

Real-time PCR assay, specificity, and sensitivity. The new real-time PCR assay using CaLsolP probe and CaLsppF/CaLsppR primers was specific for ' $\mathrm{Ca}$. L. solanacearum' targets, with a PCR product of $111 \mathrm{bp}$. All reference ' $\mathrm{Ca}$. L. solanacearum' isolates (Table 1) were amplified. No amplification occurred with 17 ' $C a$. Liberibacter' isolates causing citrus huanglongbing disease; 16 bacterial species that affect tomato, potato, pepper, and other crops; or 81 microbiota isolates from celery, carrot, and potato.

Using purified DNA (from infected celery), only two of the four conventional PCR protocols detected ' $\mathrm{Ca}$. L. solanacearum' (Table 2). The protocol of Ravindran et al. (33) that uses the Lso TX F and Lso TX F primers was the most sensitive, amplifying down to a $10^{-2}$ dilution. However, the sensitivity of the real-time PCR assays (i.e., the new assay described in this article and the assay of $\mathrm{Li}$ et al. [16]) was higher than with conventional PCR, amplifying down to a $10^{-3}$ dilution. Using spotted samples, no amplification was obtained with conventional PCR assays and only real-time PCR assays detected ' $C a$. L. solanacearum' down to a $10^{-2}$ dilution.

Comparison of sample preparation methods using naturally infected celery plants: DNA extraction versus spot. Of 502 samples tested using the new real-time PCR assay, 151 samples were positive using both DNA extraction and spot procedure. In total, 100 samples were positive using only purified DNA and one sample was positive using only spot procedure. The remaining samples were negative, independent of the sample preparation method used. The coincidence between methods was $80 \%$. The estimated prevalence (positive by both methods) was $30 \%$. The Cohen's $\kappa$ coefficient was $0.60 \pm 0.040$ and the BAK index was $0.58 \pm 0.040$.

The $\mathrm{Ct}$ values from spotted samples on nylon or paper membranes were similar (data not shown). In addition, no differences were found between DNeasy or CTAB (data not shown).

Intralaboratory validation of a complete kit. ' $\mathrm{C} a$. L. solanacearum' was detected only in the "blind" positive samples at $\mathrm{Ct}$ values of $29.8 \pm 2.2$ to $37.2 \pm 1.5$ in all three laboratories (data not shown). Similar $\mathrm{Ct}$ values were obtained with the different thermal cyclers. The calculated diagnostic parameters (sensitivity and specificity) were 1.0, indicating a $100 \%$ accuracy for the kit.

Association of ' $\mathrm{Ca}$. L. solanacearum' or phytoplasmas with symptoms. The percentage of celery plants positive for ' $\mathrm{Ca}$. L. solanacearum' in each symptom classification group were $86 \%$ in plants with severe symptoms $(+++), 42 \%$ in plants with mild symptoms (+), and $21 \%$ in symptomless plants (Table 3 ). Multinomial logistic regression analysis showed that the only significant independent variable $\left(\operatorname{Pr}<2^{-16}\right)$ was the presence of ' $C a$. L. solanacearum' whereas the presence of phytoplasmas $(\operatorname{Pr}=0.84)$ did not affect the model.

Electron microscopy observations. Bacteria-like organisms (BLOs) were observed using SEM in the phloem sieve tubes of celery samples that had tested real-time PCR positive for ' $\mathrm{Ca}$. L. solanacearum' (Fig. 2A and B). The BLOs were neither observed in the associated companion or mesophyll cells nor in symptomless celery plants testing negative for ' $\mathrm{Ca}$. L. solanacearum'. Using TEM, observed BLO cells were pleomorphic and surrounded by an electron-dense cell wall separate from the cytoplasmic membrane, which was slightly rippled, wrinkled, or uneven (Fig. 2C and D). The BLO cells were triple-layered membrane (i.e., outer cell wall membrane and the inner cytoplasmic), suggesting the presence of ' $\mathrm{Ca}$. Liberibacter' cells (Fig. 2D) rather than phytoplasma, cells which do not have a cell wall.

Phylogenetic analyses. Based on bootstrap consensus phylogenetic trees of the 16S and 50S rRNA genes, celery strains grouped into two clusters for $16 \mathrm{~S}$ rRNA (data not shown). The first cluster contained the Spanish celery isolates collected in 2007, 2009, and 2010; the carrot isolates from Finland and Spain; and one Spanish isolate recovered from B. trigonica. The second cluster contained the celery and carrot isolates collected in Spain in 2011. These clusters belonged to a broad cluster which was separated from another cluster that grouped all the tomato isolates from the United States. For 50S rDNA, celery isolates were grouped into the same clusters as for 16S rDNA (data not shown). Table 4 is based on a previous report (31), with the addition of descriptions of SNPs for the new haplotype numbered as 5 and named E. Today, this haplotype is represented by isolates from celery and carrot plants grown in Spain in 2011. A cladogram (Fig. 3) on the 16S rRNA gene shows the divergence of the different haplotypes described up to now. GenBank accession numbers were KF737346 (celery, Spain, 16S rDNA) and KF737348 (carrot, Spain, 16S rDNA).

\section{DISCUSSION}

Species of ' $\mathrm{Ca}$. Liberibacter' are emerging plant pathogens associated with economically important diseases $(5,23)$ but their causes are still not clear. Although ' $\mathrm{Ca}$. L. solanacearum' is only pathogenic to members of the family Solanaceae (18), it has also

TABLE 3. Association of symptom intensity in celery plants grown in experimental plots and detection of 'Candidatus Liberibacter solanacearum' or phytoplasmas by real-time polymerase chain reaction (PCR)

\begin{tabular}{lccccc}
\hline & \multicolumn{4}{c}{ Real-time PCR } \\
\cline { 2 - 3 } \cline { 5 - 6 } \cline { 5 - 6 } Symptoms ${ }^{\mathrm{a}}$ & \multicolumn{2}{c}{ 'Ca. L. solanacearum' } & & \multicolumn{2}{c}{ Phytoplasmas } \\
\cline { 2 - 3 } \cline { 5 - 6 } & Positive & Negative & & Positive & Negative \\
\hline+++ & 150 & 24 & & 28 & 146 \\
+ & 63 & 87 & & 25 & 125 \\
- & 38 & 140 & & 26 & 152 \\
Total & 251 & 251 & & 79 & 365 \\
\hline
\end{tabular}

a Celery plants with severe symptoms (unmarketable) $(+++)$, with mild symptoms (+), and without symptoms (-).

b Number of plants that were positive or negative for 'Candidatus Liberibacter solanacearum' or phytoplasmas by real-time PCR.

TABLE 2. Comparison of the sensitivity of conventional and real-time polymerase chain reaction (PCR)-based protocols using purified DNA and the spot procedure to detect 'Candidatus Liberibacter solanacearum' in infected celery extract ${ }^{\mathrm{a}}$

\begin{tabular}{|c|c|c|c|c|c|c|c|c|c|c|c|c|c|c|}
\hline \multirow[b]{2}{*}{ PCR protocol } & \multicolumn{7}{|c|}{ DNA extracted from crude extract serial dilutions } & \multicolumn{7}{|c|}{ Direct spot from crude extract serial dilutions } \\
\hline & 1 & 10 & $10^{-1}$ & $10^{-2}$ & $10^{-3}$ & $10^{-4}$ & $10^{-5}$ & 1 & 10 & $10^{-1}$ & $10^{-2}$ & $10^{-3}$ & $10^{-4}$ & $10^{-5}$ \\
\hline \multicolumn{15}{|l|}{ Conventional } \\
\hline Liefting et al. $(17,18)$ & + & - & - & - & - & - & - & - & - & - & - & - & - & - \\
\hline Li et al. (16) (Lsof/OI2c) & - & - & - & - & - & - & - & - & - & - & - & - & - & - \\
\hline Ravindran et al. (33) (adk) & - & - & - & - & - & - & - & - & - & - & - & - & - & - \\
\hline Ravindran et al. (33) (TX) & + & + & + & + & - & - & - & - & - & - & - & - & - & - \\
\hline \multicolumn{15}{|l|}{ Real-time } \\
\hline Li et al. (16) (Lsof/HLBr) & $+(22.8)^{*}$ & $+(25.7)^{*}$ & $+(28.4)^{*}$ & $+(33.7)^{*}$ & $+(34.5)^{*}$ & - & - & $+(28.8)^{*}$ & $+(32.5)^{*}$ & $+(34.5)^{*}$ & - & - & - & - \\
\hline This article & $+(23.6)^{*}$ & $+(26.5)^{*}$ & $+(28.3)^{*}$ & $+(31.6)^{*}$ & $+(32.5)^{*}$ & - & - & $+(28.8)^{*}$ & $+(28.2)^{*}$ & $+(34.0)^{*}$ & - & - & - & - \\
\hline
\end{tabular}

a An asterisk (*) indicates positive sample (cycle threshold). 
been associated with diseases in other botanical families such as Apiaceae in different geographical areas (23). The emergence of the disease in celery crops may be linked to the proximity of infected carrot with ' $C a$. L. solanacearum', to the presence of $B$. trigonica populations $(1,2,41)$, and probably to the existence of other psyllid vector species. Infection of carrot with ' $\mathrm{Ca}$. L. solanacearum' in different geographical areas (i.e., Finland, France, Spain, and Sweden) suggests that carrot seed might be the first source of inoculum in these countries, despite the fact that seed transmission of ' $\mathrm{Ca}$. L. solanacearum' has not yet been reported (23). The bacterium ' $C a$. L. solanacearum' was consistently detected in symptomatic celery plants using conventional PCR and confirmed by sequencing. Phytoplasmas belonging to aster yellows and stolbur groups and Celery mosaic virus (11) were sporadically detected (data not shown).

During the study period, the prevalence of symptoms in celery decreased markedly from $>30 \%$ plants in 2008 to 2010 to $<1 \%$ plants in 2011 to 2012. These figures corresponded to a decrease in ' $\mathrm{Ca}$. L. solanacearum' detection from 62 to $50 \%$ in 2009 to 2010 to 9 to $0.5 \%$ in 2011 to 2012 . The summer of 2008 was the coldest within the 2008 to 2012 period, showing only a few peaks $>30^{\circ} \mathrm{C}$. These temperatures probably favored the multiplication of ' $C a$. L. solanacearum' in plants as well as in psyllid vectors. In the following years, temperatures $>30^{\circ} \mathrm{C}$ were frequent. These high temperatures may have resulted in a decrease in the prevalence of the bacterium. Indeed, the fact that ' $\mathrm{Ca}$. L. solanacearum' was detected in greenhouse plants grown at 15 to $25^{\circ} \mathrm{C}$ but not in the same plants after 1 month at $\approx 30^{\circ} \mathrm{C}$ (data not shown) suggests that high temperature may affect prevalence of the pathogen $(21,27)$ and is worthy of further investigation.

The designed TaqMan probe was specific to ' $C a$. L. solanacearum'. The new real-time PCR protocol and the one previously described (16) showed similar sensitivity, being higher than the most sensitive conventional PCR protocol (33). Using DNA extraction, the detection level was the $10^{-4}$ dilution of the celery extract. Detection levels decreased to $10^{-2}$ dilution when spots of crude plant extracts were used as template. Real-time PCR is currently considered the most accurate and reliable method for detection and diagnosis of plant-pathogenic bacteria $(9,16,22)$. The differences in sensitivity observed between conventional and

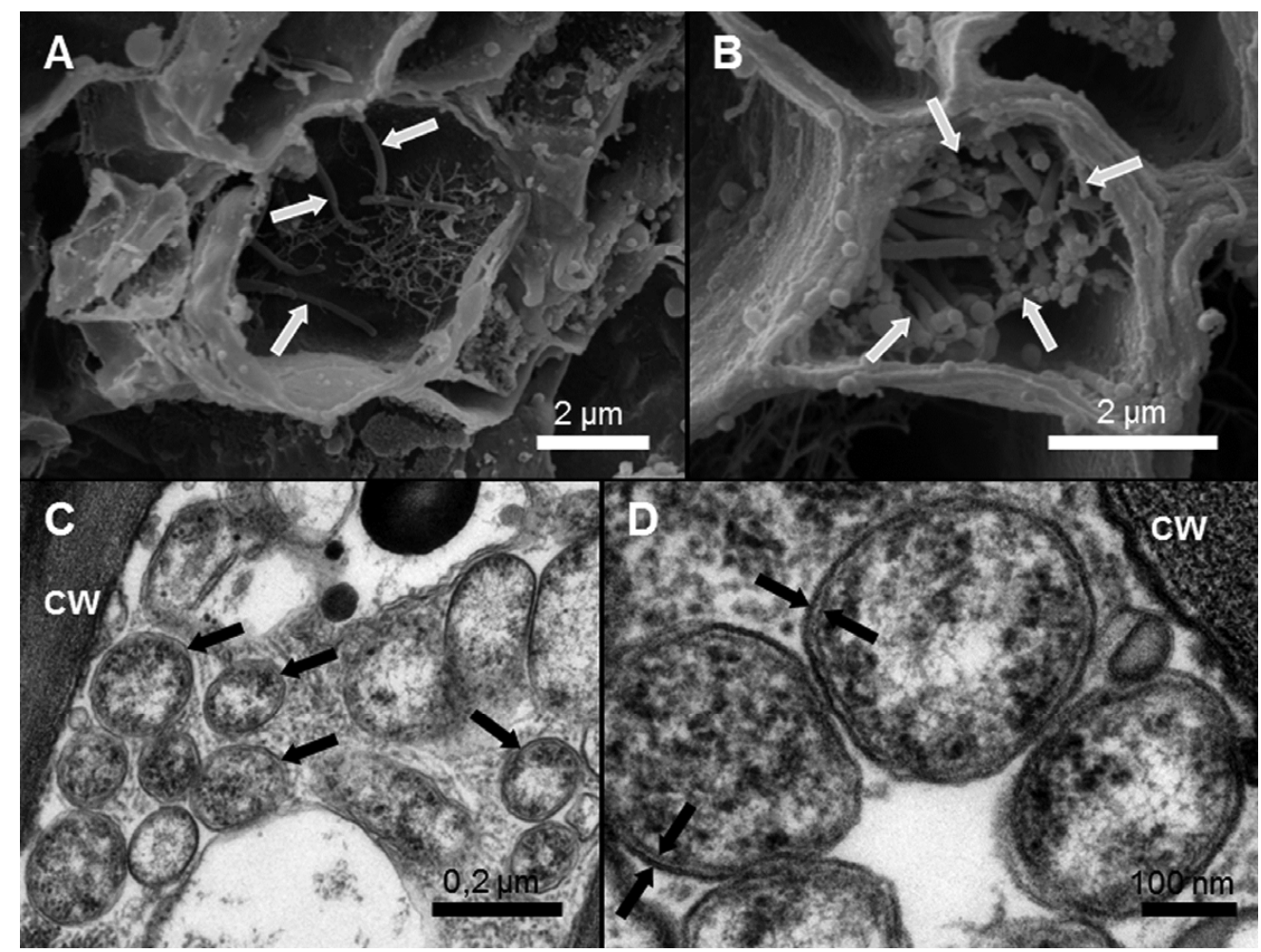

Fig. 2. Scanning (SEM) and transmission (TEM) electron microscopy photomicrographs of celery tissue samples. A and B, Presence of bacteria-like organisms (BLOs) (white arrows) in the phloem sieve tubes analyzed by SEM. C and D, TEM studies shows BLO (black arrows) individual cells pleomorphic in shape and surrounded by an electron-dense cell wall separate from the cytoplasmic membrane, slightly rippled and wrinkled. Cells showing a triple-layered ultrastructure of both the outer cell wall membrane and the inner cytoplasmic membrane (between two black arrows) suggesting the presence of 'Candidatus Liberibacter'-like cells (D). CW = plant cell wall.

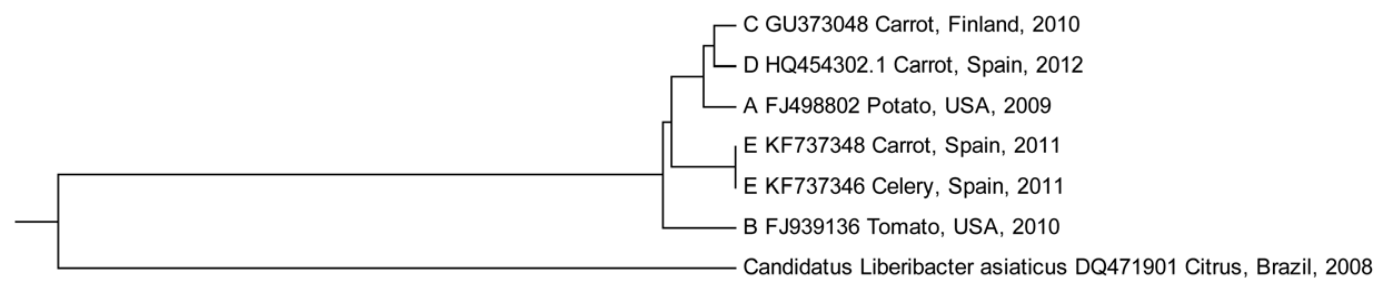

\begin{tabular}{llll}
\hline 1 & 1 & 1 & 1 \\
0.015 & 0.010 & 0.005 & 0.000
\end{tabular}

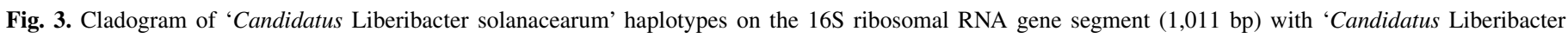
asiaticus' as the outgroup using the unweighted pairgroup method with arithmetic means algorithm. GenBank accession number and origin are indicated. 
real-time PCR in this work are related to the different levels of detection of the utilized protocols. Our results are in agreement with previously described comparative assays for ' $\mathrm{Ca}$. L. solanacearum' detection, in which real-time PCR was 10 to 100 -fold more sensitive than conventional PCR using different primers and protocols (16).

The use of friendly direct methods of sample preparation prior real-time PCR is highly recommended for large-scale use (9). In this case, we used a spot procedure as in other validated methods $(4,6,32,40)$ for ' $C a$. L. solanacearum' detection. The sensitivity and specificity of the conventional preparation of celery samples based on DNA extraction was equal to 1.0 and it was considered as a gold standard, independent from the false positives inherent to high sensitivity (22). Nevertheless, spot's sensitivity (0.60) and specificity (0.99) guarantee a low number of false positives. The calculated Cohen's $\kappa$ coefficient and the BAK index showed a moderate concordance between methods as defined by Landis and Koch (15). The agreement between spotted samples and the gold standard, the simplicity in the preparation, and the considerably

TABLE 4. Single-nucleotide polymorphism differences between haplotypes ${ }^{\mathrm{a}}$

\begin{tabular}{|c|c|c|c|c|c|}
\hline \multirow[b]{2}{*}{ Gene region, description } & \multicolumn{5}{|c|}{ Haplotypes } \\
\hline & A & $\mathrm{B}$ & $\mathrm{C}$ & $\mathrm{D}$ & $\mathrm{E}$ \\
\hline \multicolumn{6}{|l|}{$16 \mathrm{~S}$ rRNA } \\
\hline $116 \mathrm{C}>\mathrm{T}$ & $\mathrm{C}$ & $\mathrm{C}$ & $\mathrm{C}$ & $\mathrm{T}$ & $\mathrm{C}$ \\
\hline $151 A>G$ & A & A & A & A & $\mathrm{G}$ \\
\hline $212 \mathrm{~T}>\mathrm{G}$ & $\mathrm{T}$ & $\mathrm{C}$ & $\mathrm{T}$ & $\mathrm{T}$ & $\mathrm{T}$ \\
\hline $581 \mathrm{~T}>\mathrm{C}$ & $\mathrm{T}$ & $\mathrm{C}$ & $\mathrm{T}$ & $\mathrm{T}$ & $\mathrm{T}$ \\
\hline $959 \mathrm{C}>\mathrm{T}$ & $\mathrm{C}$ & $\mathrm{C}$ & $\mathrm{C}$ & $\mathrm{C}$ & $\mathrm{T}$ \\
\hline $1039 \mathrm{~A}>\mathrm{G}$ & A & A & G & G & A \\
\hline $1073 \mathrm{G}>\mathrm{A}$ & $\mathrm{G}$ & G & G & A & $\mathrm{G}$ \\
\hline \multicolumn{6}{|l|}{ ISR-23S } \\
\hline $1620 A>G$ & A & A & A & A & $\mathrm{G}$ \\
\hline $1632 \mathrm{G}>\mathrm{A}$ & A & A & A & A & $\mathrm{G}$ \\
\hline $1648 \mathrm{G}>\mathrm{A}$ & G & G & G & G & A \\
\hline $1742 \mathrm{~A}>\mathrm{G}$ & A & A & A & G & A \\
\hline $1748 \mathrm{C}>\mathrm{T}$ & $\mathrm{C}$ & $\mathrm{C}$ & $\mathrm{C}$ & $\mathrm{T}$ & $\mathrm{C}$ \\
\hline 1858_1859insG & - & $\mathrm{G}$ & G & - & - \\
\hline 1859_1860insT & - & $\mathrm{T}$ & - & - & - \\
\hline $1860-1861 \mathrm{delT}$ & $\mathrm{T}$ & $\mathrm{T}$ & $\mathrm{T}$ & - & $\mathrm{T}$ \\
\hline $1873 \mathrm{~A}>\mathrm{G}$ & A & A & A & A & G \\
\hline $1920 \mathrm{~T}>\mathrm{C}$ & $\mathrm{T}$ & $\mathrm{T}$ & $\mathrm{C}$ & $\mathrm{T}$ & $\mathrm{T}$ \\
\hline \multicolumn{6}{|l|}{ 50S rRNA } \\
\hline $583 \mathrm{G}>\mathrm{C}$ & $\mathrm{G}$ & G & $\mathrm{C}$ & G & G \\
\hline $622 \mathrm{~A}>\mathrm{G}$ & A & A & A & $\mathrm{G}$ & A \\
\hline $640 \mathrm{C}>\mathrm{T}$ & $\mathrm{C}$ & $\mathrm{C}$ & $\mathrm{T}$ & $\mathrm{C}$ & $\mathrm{C}$ \\
\hline $669 \mathrm{G}>\mathrm{C}$ & $\mathrm{G}$ & $\mathrm{C}$ & $\mathrm{G}$ & $\mathrm{G}$ & $\mathrm{G}$ \\
\hline $689 \mathrm{C}>\mathrm{T}$ & $\mathrm{C}$ & $\mathrm{C}$ & $\mathrm{C}$ & $\mathrm{T}$ & $\mathrm{T}$ \\
\hline $691 \mathrm{G}>\mathrm{T}$ & $\mathrm{G}$ & $\mathrm{T}$ & $\mathrm{T}$ & $\mathrm{G}$ & $\mathrm{G}$ \\
\hline $700 \mathrm{~A}>\mathrm{G}$ & A & A & A & G & A \\
\hline $712 \mathrm{G}>\mathrm{T}$ & G & $\mathrm{T}$ & G & G & $\mathrm{G}$ \\
\hline $722 \mathrm{G}>\mathrm{A}$ & $\mathrm{G}$ & $\mathrm{G}$ & G & $\mathrm{G}$ & A \\
\hline $749 \mathrm{C}>\mathrm{A}$ & $\mathrm{C}$ & $\mathrm{C}$ & $\mathrm{C}$ & A & $\mathrm{C}$ \\
\hline 780_781insA & - & - & A & A & A \\
\hline $785 \mathrm{G}>\mathrm{A}$ & G & A & G & G & $\mathrm{G}$ \\
\hline $849 \mathrm{~T}>\mathrm{C}$ & $\mathrm{T}$ & $\mathrm{T}$ & $\mathrm{T}$ & $\mathrm{C}$ & $\mathrm{C}$ \\
\hline $909 \mathrm{~T}>\mathrm{C}$ & $\mathrm{T}$ & $\mathrm{C}$ & $\mathrm{C}$ & $\mathrm{C}$ & $\mathrm{C}$ \\
\hline $920 \mathrm{~T}>\mathrm{C}$ & $\mathrm{T}$ & $\mathrm{C}$ & $\mathrm{C}$ & $\mathrm{C}$ & $\mathrm{T}$ \\
\hline 922_923insTGT & - & - & TGT & - & - \\
\hline $955 \mathrm{G}>\mathrm{T}$ & G & G & $\mathrm{T}$ & G & G \\
\hline $987 \mathrm{~T}>\mathrm{G}$ & $\mathrm{T}$ & $\mathrm{G}$ & G & $\mathrm{G}$ & G \\
\hline $993 \mathrm{~A}>\mathrm{G}$ & A & A & G & A & A \\
\hline $1041 \mathrm{G}>\mathrm{A}$ & G & A & A & G & G \\
\hline $1049 A>G$ & A & $\mathrm{G}$ & A & A & A \\
\hline $1068 \mathrm{C}>\mathrm{T}$ & $\mathrm{C}$ & $\mathrm{C}$ & $\mathrm{C}$ & $\mathrm{C}$ & $\mathrm{C}$ \\
\hline $1107 \mathrm{G}>\mathrm{A}$ & $\mathrm{G}$ & A & $\mathrm{G}$ & $\mathrm{G}$ & $\mathrm{G}$ \\
\hline 1110_1111insC & - & - & $\mathrm{C}$ & - & - \\
\hline $1122 \mathrm{G}>\mathrm{A}$ & $\mathrm{G}$ & $\mathrm{A}$ & A & A & A \\
\hline $1143 \mathrm{G}>\mathrm{A}$ & G & A & G & G & G \\
\hline
\end{tabular}

a The reference sequence for the $16 \mathrm{~S}$ and $23 \mathrm{~S}$ ribosomal RNA (rRNA) genes is EU 812559.1 and for 50S rRNA gene is EU 834131.1. Nucleotide numbers count from the beginning of the reference sequence (haplotypes $\mathrm{A}$, $\mathrm{B}, \mathrm{C}$, and D), as previously described by Nelson et al. $(30,31)$. lower cost compared with DNA purification confirm the appropriateness of the spot method for detection of ' $\mathrm{Ca}$. L. solanacearum' and for large-scale screening purposes.

The efficacy of a commercially available complete kit was demonstrated through intralaboratory performance studies, showing an excellent sensitivity and specificity. The recommended kit's real-time protocol differs from the protocol that uses fresh master mix in four degrees $\left(64\right.$ instead of $60^{\circ} \mathrm{C}$ ) for the amplification reaction. In fact, in previous assays, lyophilization was shown to alter the specificity of the TaqMan probes.

In carrot plants, mixed infections of ' $\mathrm{Ca}$. L. solanacearum' and phytoplasmas are frequently detected (1) and it was not possible to associate either pathogen with the symptoms observed. In celery plants, mixed infections were less frequent and, in multinomial logistic regression analysis, the presence of ' $\mathrm{Ca}$. L. solanacearum' was the only significant independent variable. Although these results may be considered to be false negatives due to the possible presence of PCR inhibitors, it is very likely that the symptoms in these plants were caused by other pathogens, such as phytoplasmas, because visual description of symptoms is not fully specific to ' $C a$. L. solanacearum'. In addition, only typical ' $\mathrm{Ca}$. Liberibacter'-like cells with an electron-dense cell wall layer with a triple-layered ultrastructure (5) were observed in microscopic examinations by TEM and SEM (Fig. 2).

Four ' $\mathrm{Ca}$. L. solanacearum' haplotypes (designated A, B, C, and D) have been described affecting several crops worldwide. Haplotypes are described from SNPs that are inherited as a package in three gene regions: $16 \mathrm{~S}$ rRNA, $16 \mathrm{~S} / 23 \mathrm{~S}$ ISR, and 50s rRNA $(30,33)$. Haplotype A has been found from Central to North America and in New Zealand, whereas haplotype B has been found in Mexico and North America. Both haplotypes are present in solanaceous crops and are transmitted by the vector $B$. cockerelli (30). Haplotype $\mathrm{C}$ is present in Finland and was first described in carrot in association with the carrot psyllid $T$. apicalis (30). Haplotype D was described in mainland Spain and the Canary Islands, associated with carrot and $B$. trigonica $(23,31)$. The new haplotype $\mathrm{E}$ was characterized by five nucleotide changes in the $16 \mathrm{~S}$ rDNA, seven in the ISR-23S, and five in the 50S rDNA regions. The spatial and temporal coexistence of the same haplotypes in carrot and celery suggests natural transmission between both plant species.

$B$. cockerelli, the vector of the zebra chip disease, has never been detected in Spain. Haplotypes D and E detected in carrot and celery plants could be associated with their natural spread by $B$. trigonica and maybe by other psyllid species. The almost permanent presence of ' $\mathrm{Ca}$. L. solanacearum' during the year in carrot and celery crops, even in symptomless plants, could also contribute to the spread of the bacterium.

In conclusion, we have demonstrated that the bacterium ' $\mathrm{Ca}$. L. solanacearum' is directly associated with a vegetative disorder in celery in Spain. The developed real-time PCR detection system and the newly discovered haplotype of this bacterium expands our knowledge of ' $C a$. L. solanacearum' and will improve our ability to develop appropriate control strategies.

\section{ACKNOWLEDGMENTS}

This work was supported by grants from Generalidad Valenciana, MAGRAMA (National Reference Laboratories), INIA (RTA201100142), Agrícola Villena Coop. V. from Spain, and FP7-ERANET EUPHRESCO (266505/PHYLIB). E. Bertolini is recipient of an INIACCAA 2011-2016 contract from Ministerio de Ciencia e Innovación, Spain and G. R. Teresani is recipient of Ph.D. grant 2010-2014 from Coordenação de Aperfeiçoamento de Pessoal de Nível Superior (CAPES), Ministério da Educação, Brazil. We thank J. M. Bové for the kind supply of the ' $\mathrm{Ca}$. Liberibacter' isolates maintained at INRABordeaux-France; M. Colomer from Plant Print Diagnòstics S.L. for preparation of kit prototypes; C. Jeffries and V. Mulholland from SASA, Edinburgh, UK and M. Cambra-López for the critical reading of the 
manuscript and excellent suggestions; and P. Bartolomé from Agrícola Villena Coop. V. for assistance in sample collection. This paper is dedicated to the memory of M. Garnier (1949-2003) and F. J. Villaescusa (1981-2011).

\section{LITERATURE CITED}

1. Alfaro-Fernández, A., Cebrián, M. C., Villaescusa, F. J., Hermoso de Mendoza, A., Ferrándiz, J. C., Sanjuán, S., and Font, M. I. 2012. First report of 'Candidatus Liberibacter solanacearum' in carrots in mainland Spain. Plant Dis. 96:582.

2. Alfaro-Fernández, A., Siverio, F., Cebrián, M. C., Villaescusa, F. J., and Font, M. I. 2012. 'Candidatus Liberibacter solanacearum' associated with Bactericera trigonica-affected carrots in the Canary Islands. Plant Dis. 96:581.

3. Bertolini, E., Cambra, M., Serra, P., López, M. M., Lopes, S., Duran-Vila, N., Ayres, J., and Bové, J. M. 2010. Direct procedures for specific detection of 'Candidatus Liberibacter' spp. using immobilized targets and real-time PCR and detection kit. Spanish patent 201001157.

4. Bertolini, E., Moreno, A., Capote, N., Olmos, A., De Luis, A., Vidal, E., Pérez-Panadés, J., and Cambra, M. 2008. Quantitative detection of Citrus tristeza virus in plant tissues and single aphids by real-time PCR. Eur. J. Plant Pathol. 120:177-188.

5. Bové, J. M. 2006. Huanglongbing: a destructive, newly-emerging, century-old disease of citrus. J. Plant Pathol. 88:7-37.

6. Byrt, T., Bishop, J., and Carlin, J. B. 1993. Bias, prevalence and kappa. J. Clin. Epidemiol. 46:423-429.

7. Capote, N., Bertolini, E., Olmos, A., Vidal, E., Martinez, M. C., and Cambra, M. 2009. Direct sample preparation methods for the detection of Plum pox virus by real-time RT-PCR. Int. Microbiol. 12:1-6.

8. Crosslin, J. M., Munyaneza, J. E., Brown, J. K., and Liefting, L. W. 2010. Potato zebra chip disease: a phytopathological tale. Plant Health Progress. Online publication. doi:10.1094/PHP-2010-0317-01-RV

9. De Boer, S. H., and López, M. M. 2012. New grower-friendly methods for plant pathogen monitoring. Annu. Rev. Phytopathol. 50:197-218.

10. EPPO. 2013. Data sheets on pests recommended for regulation. 'Candidatus Liberibacter solanacearum'. Bull. OEPP/EPPO Bull. 43:197-201.

11. Font, M. I., Cebrián, M. C., Villaescusa, F. J., Córdoba, M. C., Ferrándiz, J. C., Sanjuán, S., Alfaro-Fernández, A., Hermoso de Mendoza, A., and Jordá, C. 2010. First report of phytoplasmas disease in celery and parsnip in Spain. Petria 20:260-261.

12. Hansen, A. K., Trumble, J. T., Stouthamer, R., and Paine, T. D. 2008. A new huanglongbing species, "Candidatus Liberibacter psyllaurous," found to infect tomato and potato, is vectored by the psyllid Bactericera cockerelli (Sulc). Appl. Environ. Microbiol. 74:5862-5865.

13. Hren, M., Boben, J., Rotter, A., Kralj, P., Gruden, K., and Ravnikar, M. 2007. Real-time PCR detection systems for Flavescence dorée and Bois noir phytoplasmas in grapevine: comparison with conventional PCR detection and application in diagnostics. Plant Pathol. 56:785-796.

14. Kumar, S., Tamura, K., and Nei, M. 2004. MEGA3: integrated software for molecular evolutionary genetics analysis and sequence alignment. Brief. Bioinf. 5:150-163.

15. Landis, J. R., and Koch, G. G. 1977. The measurement of observer agreement for categorical data. Biometrics 33:159-174.

16. Li, W., Abad, J. A., French-Monar, R. D., Rascoe, J., Wen, A., Gudmestad, N. C., Secor, G. A., Lee, I. M., Duan, Y., and Levy, L. 2009. Multiplex real-time PCR for detection, identification and quantification of 'Candidatus Liberibacter solanacearum' in potato plants with zebra chip. J. Microbiol. Methods 78:59-65.

17. Liefting, L. W., Sutherland, P. W., Ward, L. I., Paice, K. L., Weir, B. S., and Clover, G. R. G. 2009. A new 'Candidatus Liberibacter' species associated with diseases of solanaceous crops. Plant Dis. 93:208-214.

18. Liefting, L. W., Weir, B. S., Pennycook, S. R., and Clover, G. R. G. 2009. 'Candidatus Liberibacter solanacearum', a Liberibacter associated with plants in the family Solanaceae. Int. J. Syst. Evol. Microbiol. 59:22742276.

19. Lin, H., Doddapaneni, H., Munyaneza, J. E., Civerolo, E., Sengoda, V. G., Buchman, J. L., and Stenger, D. C. 2009. Molecular characterization and phylogenetic analyses of 16S rRNA from a new species of 'Candidatus Liberibacter' associated with zebra chip disease of potato (Solanum tuberosum L.) and the potato psyllid (Bactericera cockerelli Sulc). J. Plant Pathol. 91:215-219.

20. Lin, H., Glynn, J., Islam, M. S., Wen, A., and Gudmestad, N. C. 2011. Multilocus sequencing typing markers for genotyping and population genetic analysis of 'Candidatus Liberibacter solanacearum'. Pages 32-35 in: Proc. 11th Annu. Zebra Chip Rep. Session, San Antonio, TX. F. Workneh, A. Rashed, and C. M. Rush, eds.
21. Lopes, S. A., Frare, G. F., Bertolini, E., Cambra, M., Fernandez, N. G., Ayres, A. J., Marin, D. R., and Bové, J. M. 2009. Liberibacters associated with citrus huanglongbing in Brazil: 'Candidatus Liberibacter asiaticus' is heat tolerant, 'Candidatus Liberibacter americanus' is heat sensitive. Plant Dis. 93:257-262.

22. López, M. M., Llop, P., Olmos, A., Marco-Noales, E., Cambra, M., and Bertolini, E. 2009. Are molecular tools solving the challenges posed by detection of plant pathogenic bacteria and viruses? Curr. Issues Mol. Biol. 11:13-46.

23. Munyaneza, J. E. 2012. Zebra chip disease of potato: biology, epidemiology and management. Am. J. Pot. Res. 89:329-350.

24. Munyaneza, J. E., Crosslin, J. M., and Upton, J. E. 2007. Association of Bactericera cockerelli (Homoptera: Psyllidae) with "zebra chip", a new potato disease in southwestern United States and Mexico. J. Econ. Entomol. 100:656-663.

25. Munyaneza, J. E., Fisher, T. W., Sengoda, V. G., and Garczynski, S. F. 2010. First report of 'Candidatus Liberibacter solanacearum' associated with psyllid-affected carrots in Europe. Plant Dis. 94:639.

26. Munyaneza, J. E., Fisher, T. W., Sengoda, V. G., Garczynski, S. F., Nissinen, A., and Lemmetty, A. 2010. Association of 'Candidatus Liberibacter solanacearum' with the psyllid Trioza apicalis (Hemiptera: Triozidae) in Europe. J. Econ. Entomol. 103:1060-1070.

27. Munyaneza, J. E., Sengoda, V. G., Buchman, J. L., and Fisher, T. W. 2012. Effects of temperature on 'Candidatus Liberibacter solanacearum' and zebra chip potato disease symptom development. Plant Dis. 96:18-23.

28. Munyaneza, J. E., Sengoda, V. G., Crossling, J. M., Rosa-Lozano, G., and Sanchez, A. 2009. First report of 'Candidatus Liberibacter psyllaurous' in potato tubers with zebra chip disease in Mexico. Plant Dis. 93:552.

29. Murray, M. G., and Thompson, W. F. 1980. Rapid isolation of high molecular weight plant DNA. Nucleic Acids Res. 8:4321-4325.

30. Nelson, W. R., Fisher, T. W., and Munyaneza, J. E. 2011. Haplotypes of 'Candidatus Liberibacter solanacearum' suggest long-standing separation. Eur. J. Plant Pathol. 130:5-12.

31. Nelson, W. R., Sengoda, V. G., Alfaro-Fernández, A., Font, M. I., Crossling, J. M., and Munyaneza, J. E. 2012. A new haplotype of 'Candidatus Liberibacter solanacearum' identified in the Mediterranean region. Eur. J. Plant Pathol. 135:633-639.

32. Olmos, A., Dasi, M. A., Candresse, T., and Cambra, M. 1996. Printcapture PCR: a simple and highly sensitive method for the detection of Plum pox virus (PPV) in plant tissues. Nucleic Acids Res. 24:2192-2193.

33. Ravindran, A., Levy, J., Pierson, E., and Gross, D. C. 2011. Development of primers for improved PCR detection of the potato zebra chip pathogen, 'Candidatus Liberibacter solanacearum'. Plant Dis. 95:1542-1546.

34. Ravindran, A., Levy, J., Pierson, E., and Gross, D. C. 2011. LAMP PCR lights the way for a simple, fast method for detection of Lso in infected potatoes and psyllids, Pages 79-82 in: Proc. 11th Annu. Zebra Chip Rep. Session, San Antonio, TX. F. Workneh, A. Rashed, and C. M. Rush, eds.

35. Reynolds, E. S. 1963. Use of lead citrate at high $\mathrm{pH}$ as an electronopaque stain in electron microscopy. J. Cell Biol. 17:208-213.

36. Schneider, R. W. 2013. Diseases of celery (Apium graveolens L. var. dulce (Mill.) Pers.). American Phytopathological Society, St. Paul, MN.

37. Scott, I., Berry, N., Walker, G., Pitman, A., Workman, P., and Wright, P. 2009. Psyllid, Liberibacter, and phytoplasma science research programme update. Horticulture New Zealand, Plant and Food Research. Online publication. doi:10.1094/PHP-2010-0317-01-RV

38. Secor, G. A., Rivera-Varas, V., Abad, J. A., Lee, I. M., Clover, G. R. G, Liefting, L. W., Li, X., and De Boer, S. H. 2009. Association of 'Candidatus Liberibacter solanacearum' with zebra chip disease of potato established by graft and psyllid transmission, electron microscopy, and PCR. Plant Dis. 93:574-583.

39. Tanaka, F. A. O., Coletta-Filho, H. D., Alves, K. C. S., Spinelli, M. O., Machado, M. A., and Kitajima, E. W. 2006. Detection of the "Candidatus Liberibacter americanus" in phloem vessels of experimentally infected Cataranthus roseus by scanning electron microscopy. Fitopatol. Bras. 32:519.

40. Vidal, E., Yokomi, R. K., Moreno, A., Bertolini, E., and Cambra, M. 2012. Calculation of diagnostic parameters of advanced serological and molecular tissue-print methods for detection of Citrus tristeza virus: a model for other plan pathogens. Phytopathology 102:114-121.

41. Villaescusa, F. J., Sanjuán, S., Cebrián, M. C., Alfaro-Fernández, A., Font, M. I., Ferrándiz, J. C., and Hermoso de Mendoza, A. 2011. Prospección de posible vectores (Hemiptera: Cicadellidae, Aphididae y Psylloideae) de patógenos en apio y zanahoria. Bol. San. Veg. Plagas. 37:163-171.

42. Wen, A., Lin, H., and Gudmestad, N. C. 2011. Development of PCR assay using SSR primers for detection and genotyping of 'Candidatus Liberibacter solanacearum'. Pages 74-78 in: Proc. 11th Annu. Zebra Chip Rep. Session, San Antonio, TX. F. Workneh, A. Rashed, and C. M. Rush, eds. 